\title{
DNA vaccine: the miniature miracle
}

\author{
Karthik Kumaragurubaran and Karthik Kaliaperumal \\ Indian Veterinary Research Institute, \\ Izatnagar - 243122, Dist. Bareilly (UP) India \\ Corresponding author: Karthik Kumaragurubaran, email:karthik_2bvsc@yahoo.co.in \\ Received: 01-07-2012, Accepted: 21-08-2012, Published online: 14-01-2013
}

How to cite this article:

Kumaragurubaran K and Kaliaperumal K (2013) DNA Vaccine: the miniature miracle, Vet. World 6(4): 228-232, doi: 10.5455/ vetworld.2013.228-232

\begin{abstract}
DNA, the essential part of the life is making way in to new vaccine technology. Plasmid vectors from the bacteria have revolutionized the world of vaccine design by its new technology - DNA vaccines. Small portion of the nucleotides from the pathogen held under the control of promoter in a plasmid vector can be used as a vaccine. DNA vaccines alleviate the odds of the other vaccines by having good hold on both the faces of the immunity. The key to the success of DNA vaccine lies in the route of administration of the vaccine which can be done in many ways. Prime boost strategy is an approach used to boost the action of DNA vaccine. To date there are only four DNA vaccine available in the market.
\end{abstract}

Key words: DNA vaccine, plasmid vector, prime boost approach, transgene

\section{Introduction}

Vaccine has a prime role in controlling and eradicating lot of dreadful diseases both in animals and humans throughout the world. Except the term vaccine nothing is constant from the era of Edward Jenner, who first immunized James Phipps against small pox in 1796 [1]. Construction of vaccines has undergone lot of mutations starting from live attenuated to the gene based vaccines. Over the years knowledge about the different corners of the vaccines has been to the limelight. Now-a-days every immunological aspect, mechanism of vaccine action is clearly unearthed. We are in the genome era where DNA, the crux of life is being used for vaccine production.

\section{Vaccines in current use}

Vaccines can be classified into five types as:

1) Live attenuated,

2) Inactivated or killed,

3) Subunit vaccine,

4) Toxoids

5) Gene based vaccines [2].

1) Live attenuated: These vaccines are prepared by making the organism avirulent by passaging it repeatedly. They can effectively induce both arms of the immunity i.e. humoral and cell mediated. Example of this kind is the well known BCG (Bacillus Calmette Guerin) vaccine against tuberculosis. The major threat here is that there may be chance for turning back to virulence [3].

2) Killed vaccines: These vaccines are prepared by inactivating the micro organisms by chemicals or by treatment with gamma rays. They can induce only humoral immunity. The advantage is that it cannot shift gears back to virulent state as that of previous vaccine. Example of this variety is Typhoid vaccine [3].

3) Subunit vaccines: Subunit vaccines contain the purified part of the antigenic proteins like flagella, capsule, etc. They are poorly immunogenic and require boosters. Example of this kind is the Haemophilus influenza B (Hib) vaccine [3].

4) Toxoids: Toxoids are inactivated bacterial toxins, which can elicit antibody response. It requires boosters for good immunity. Clostridium tetani toxoid is an example of this variety [3].

\section{DNA vaccines}

DNA vaccines are the gene based vaccines which involves recombinant DNA technology, in which a gene of interest (transgene), coding for target protein from a pathogen is carried by a plasmid vector under the control of a strong eukaryotic promoter [4]. DNA vaccines have been denoted by different names as polynucleotide vaccine, genetic vaccine, somatic transgene, nucleic acid vaccines. The official term adopted by World Health Organisation (WHO) is Nucleic acid vaccine [5]. The use of DNA by Tang et al., in 1992 was the first literature evidence in which Human growth hormone (hGH) was introduced into mice [6]. A comparative feature of the vaccines in current use is given in the Table-1.

Engineering a DNA vaccine: Plasmid vector is the key part in the DNA vaccine design.

Plasmid vector: To be a good vector there are certain demanding qualities required. It should have an origin of replication, selection marker and the important multiple cloning sites [7]. Commonly used vector for 
Table -1. A comparative feature of the vaccines in current use

\begin{tabular}{|c|c|c|c|}
\hline Type of vaccine & Advantages & Disadvantages & Example \\
\hline Live attenuated & $\begin{array}{l}\text { Induce both arms of immunity } \\
\text { Produces memory }\end{array}$ & $\begin{array}{l}\text { Less stable } \\
\text { Reversion to virulence }\end{array}$ & BCG vaccine \\
\hline Killed & $\begin{array}{l}\text { Can be used in immune compromised patience } \\
\text { Sufficient humoral immunity }\end{array}$ & $\begin{array}{l}\text { No cellular immunity } \\
\text { Need boosters }\end{array}$ & Typhoid vaccine \\
\hline Subunit & $\begin{array}{l}\text { Can be prepared against capsulated organism } \\
\text { Can be produced in large scale }\end{array}$ & $\begin{array}{l}\text { Serological variability } \\
\text { Need boosters }\end{array}$ & $\begin{array}{l}\text { Haemophilus influenza B (Hib) } \\
\text { vaccine }\end{array}$ \\
\hline Toxoids & $\begin{array}{l}\text { Induce humoral response } \\
\text { Can be produced in large scale }\end{array}$ & $\begin{array}{l}\text { Don't induce long lasting immunity } \\
\text { Possible adverse reactions }\end{array}$ & Tetanus toxoid \\
\hline DNA vaccines & $\begin{array}{l}\text { Induce both arms of immunity } \\
\text { Designing is simple } \\
\text { Highly stable even at room temperature } \\
\text { Less cost of making } \\
\text { Storage and transport are easy }\end{array}$ & $\begin{array}{l}\text { Plasmid integration } \\
\text { Mutagenesis } \\
\text { Tolerance induction }\end{array}$ & Canine Melanoma Vaccine \\
\hline
\end{tabular}

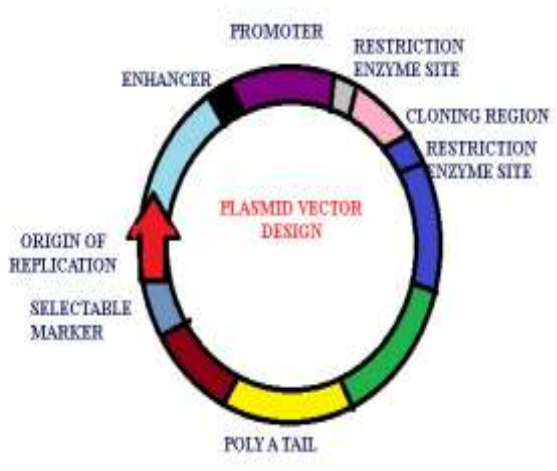

Figure-1. Pictorial representation of a plasmid vector

the making of DNA vaccine is the pVax1 which contains pUC or pBR322 origin of replication in order to express the genes in eukaryotes, which is the target for the genes incorporated. A schematic representation of the plasmid vector design is given in the figure- 1 .

\section{Transcriptional unit}

Transcriptional unit plays a major role for the expression of the desired gene. Transcriptional unit is sub divided into 3 portions namely Promoter, Transgene and Poly A tail.

Promoter: Commonly viral promoters like Cytomegalo virus (CMV), Rous sarcoma virus (RSV) and Simian virus 40 (SV40) are used to promote the transgene kept under its control. Among this CMV is the strongest promoter and used often. But cytokines regulate the CMV promoter in two different ways. Interleukin 4 (IL-4), IL-1ß, Tissue Necrosis Factor $\alpha(\mathrm{TNF} \alpha)$ up regulates the action of CMV while Interferon gamma (IFN- $\gamma$ ), IL-10 down regulates its action [8]. Chimeric SV40-CMV promoters are also tried which shows good expression of the desired gene [9]. Non viral promoters like Major histocompatibility complex (MHC) class II promoters also have the capability for use in vaccine construct [10].

Transgene: Foreign gene which is the gene of interest is called the transgene. These genes code for the proteins which will kindle the immunity against the pathogen. The advantage in DNA vaccine construct is that multiple genes can be encoded in order to give protection against different variants, which gives rise to the Bi-cistronic or Multi-cistronic vaccine [8].
Poly adenyation sequence (poly A tail) : Poly A tail is the addition of repeated adenyl residues at the 3 prime ends. This is essential for stability of mRNA [11]. Most vectors uses SV40 poly A tail. The list of commonly used plasmids for DNA vaccine construction is enlisted in Table-2. Schematic representation of the DNA vaccine construction is given in the figure- 2 .

\section{DNA vaccines delivery methods}

To get the effective vaccine effect it is mandatory to find a good route of delivery. Skin being the largest area in the body has been the hunting ground for scientists to deliver vaccines and drugs [14]. The advantage of skin is that it is easily approachable; it contains Langerhan cells, antigen presenting cells and migrating lymphocyte cells, which make it a perfect route to manipulate the immune system. There are different techniques for delivering DNA vaccine through skin.

1) Subcutaneous or intra dermal injections: This can be done injections, in which there is no need for special equipments $[12,13]$ or the more recent and fascinating method called the tattooing [14]. Tattooing is an invasive procedure by which naked plasmid DNA is injected into the skin through thousands of punctures using multiple needle tattoo device which oscillates at frequency of 145 Hertz [15].

2) Topical: Dermal patches with nano paticles can be employed in order to deliver the vaccine to the langerhan cells [16].

3) Painting DNA: Stripping few layers of skin and then 
Table-3. Comparative features of the different methods of delivery of DNA vaccines

\begin{tabular}{|c|c|c|}
\hline Mode of delivery & Advantages & Disadvantages \\
\hline Gene Gun & $\begin{array}{l}\text { DNA bombarded directly into cells } \\
\text { Requires little quantity of DNA }\end{array}$ & Requires inert particles such as gold for carrying DNA \\
\hline $\begin{array}{l}\text { Intramuscular or Intradermal } \\
\text { injection }\end{array}$ & $\begin{array}{l}\text { No special delivery mechanism } \\
\text { Spread of DNA is fast throughout the body }\end{array}$ & Needs large amount of DNA for induction of immunity \\
\hline Jet injection & $\begin{array}{l}\text { No need of carriers } \\
\text { Delivered directly under few mm of skin }\end{array}$ & $\begin{array}{l}\text { High pressure causes shearing of DNA } \\
\text { Expression of DNA is lower } \\
\text { Requires large amounts of DNA (up to } 300 \mu \mathrm{g} \text { ) }\end{array}$ \\
\hline Liposome-mediated delivery & $\begin{array}{l}\text { Higher immune response can be generated } \\
\text { Can increase transfection of intravenously } \\
\text { delivered pDNA } \\
\text { Oral delivery is possible by this method }\end{array}$ & $\begin{array}{l}\text { Toxicity can occur } \\
\text { Risk of disease or immune reactions }\end{array}$ \\
\hline Tattooing & $\begin{array}{l}\text { Induce higher CMI, humoral immunity } \\
\text { Tattooing causes trauma which attracts } \\
\text { leucocytes for the production of inflammation } \\
\text { Large surface area of skin can be utilized } \\
\text { for the production of immunity }\end{array}$ & $\begin{array}{l}\text { Causes local trauma } \\
\text { It is a painful procedure }\end{array}$ \\
\hline
\end{tabular}

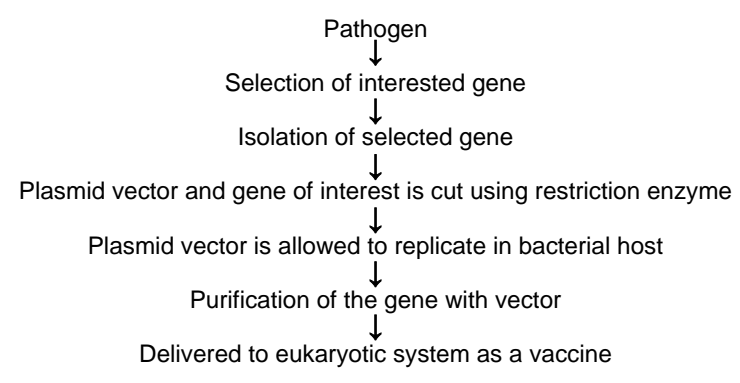

Figure-2. Schematic presentation of a DNA vaccine construction

applying the vaccine over the breached area of the skin [17].

4) Gene gun: Cells can be directly bombarded with gold nano particles which are coated with DNA. The advantages of gene gun technique over others is that this technique requires lesser DNA, coated particles are stable, cold chain is not needed and the main advantage which will bring smiles in the face of patients is that there is no needle pricks [18]. In gene gun method gold coated beads enter directly the cytoplasm and hence there are increased chances for targeting more antigen presenting cells $[9,19]$.

5) Delivery assisted by vesicular system: Intact skin can be crossed by carriers like liposomes, niosomes, ethosomes [20]. Other routes like vaginal mucosa [21], intra nasal [22], and oral [23] are the other routes which can be employed for administration of DNA vaccine.

Of all the methods of delivery of DNA vaccine mentioned above, DNA tattooing has given promising results in inducing both arms of the immunity. Pain produced by the procedure is the only disadvantage of tattooing. Comparative features of the different methods of delivery of DNA vaccines are given in the Table-3.

\section{Mode of action of DNA vaccine}

The magical action of DNA vaccine starts once the DNA enters the myocytes [6] and the antigen presenting cells [24] which are present at the site of entry. Decoding of the gene of interest takes place in the nucleus of the cells and the mRNA formed rips out of the nucleus and gets into the cytoplasm. Protein synthesis occurs in the cytoplasm. The fate of these proteins dictates the immunity to the particular pathogen. The peptides formed can be presented by MHC class I to immune system, carried out by the Antigen presenting cells (APCs). This presentation can happen by direct transfection or by cross presentation [25]. The antigenic protein which is spilled out can be taken up by APCs and can present it MHC class II [26]. APCs takes up these proteins to the regional lymph nodes where naive $\mathrm{T}$ cells are kick started to form mature $T$ cells [27]. T cells which are activated produce cytokines and the B cells which are charged up by the shed proteins produce antibodies. The initial line of B and $\mathrm{T}$ cell activation is less but once these cells migrate to the vaccine induced cells, they go for further stimulation. This is the time when $\mathrm{CD}^{+} \mathrm{T}$ cells can lyse the transfected muscle cells and also $\mathrm{CD}^{+} \mathrm{T}$ cell to activate immature dendritic cells to produce a whole new set of $\mathrm{B}$ and $\mathrm{T}$ cells [3]. Thus the DNA vaccines target both the edges of the immune system; humoral and cell mediated immunity.

\section{Positives of DNA vaccine}

1. The striking feature of DNA vaccine is that it can gear up both the arms of immunity.

2. Risk of reversion to the virulence is nill in case of DNA vaccine as compared with the live attenuated vaccine.

3. Since DNA is highly stable, it can be stored at room temperature.

4. Rapid manufacturing time.

5. Storage and transport is easy [28].

\section{Negatives of DNA vaccine}

1. Chance of developing auto immune disorders.

2. Risk of transfer of antibiotic resistance gene. 
Table-4. Features of the DNA vaccines approved for use

\begin{tabular}{|c|c|c|c|c|c|}
\hline Vaccine target & Product name & Marketed by & $\begin{array}{l}\text { Year of license } \\
\text { and country }\end{array}$ & Target organisms & Features \\
\hline West Nile virus & West Nile Innovator & $\begin{array}{l}\text { Centers for Disease Control } \\
\text { and Prevention and Fort Dodge } \\
\text { Laboratories }\end{array}$ & 2005 USA & Horses & $\begin{array}{l}\text { Act as a defence against West Nile } \\
\text { virus infection }\end{array}$ \\
\hline $\begin{array}{l}\text { Infectious haematopoietic } \\
\text { necrosis virus }\end{array}$ & Apex-IHN & Novartis & 2005 Canada & Salmon fish & $\begin{array}{l}\text { Improves animal welfare, increase } \\
\text { food quality and quantity }\end{array}$ \\
\hline $\begin{array}{l}\text { Growth hormone releasing } \\
\text { hormone }\end{array}$ & LifeTide-SW5 & VGX Animal Health & 2007 Australia & $\begin{array}{l}\text { Swine and food } \\
\text { animals }\end{array}$ & $\begin{array}{l}\text { Increases the number of piglets } \\
\text { weaned in breeding sows and } \\
\text { helps to significantly decreases } \\
\text { perinatal mortality and morbidity }\end{array}$ \\
\hline Melanoma & Canine Melanoma Vaccine & $\begin{array}{l}\text { Merial, Memorial Sloan-Kettering } \\
\text { Cancer Center and The Animal } \\
\text { Medical Center of New York }\end{array}$ & $\begin{array}{l}2007 \text { USA, } \\
\text { conditional } \\
\text { license }\end{array}$ & Dogs & $\begin{array}{l}\text { For the treatment of aggressive form of } \\
\text { cancer of the mouth, nail bed, foot pad } \\
\text { and serves as an alternative to surgery }\end{array}$ \\
\hline
\end{tabular}

3. Possibility of developing auto antibodies against immune adjutants.

4. Due to integration of foreign DNA into host, can lead to insertional mutagenesis [28].

\section{I mproving immunogenicity}

Even though there are lot of positive points of DNA vaccines still it in the infant stage. In order to enhance the immunogenic capacity of DNA vaccine certain strategies can be followed.

1. Codon optimization: Codon bias is seen in case of E.coli strains. Hence it is better to change the codon sequence which is commonly used in those strains in order to get good translation [29]. This process is also called as 'Humanization of codons' [29].

2. Untranslated regions: Inclusion of Kozak consensus sequence can increase the expression and mRNA stability [30].

3. Cytosine phosphate guanine motifs (CpG): Unmethylated $\mathrm{CpG}$ motifs from the prokaryotes activate Toll like receptor 7 (TLR-7). Thus they stimulate B lymphocytes and plasmocytoid dendritic cells thereby regulating innate and acquired immunity [31].

\section{Prime boost approach}

DNA vaccines are less effective compared to attenuated vaccine and inactive vaccines. In order to increase the immunity the DNA vaccines can be given repeatedly. Heterologous vaccination regime can be used in order to induce the immunity. This strategy is followed in order to alleviate the disadvantage of DNA vaccine, that it induces low immunity and needs boosters. In this approach first dose is given as naked DNA by gene gun followed by boosting with the same recombinant protein carried by a vector [32]. This has been useful in case of proteins which are poorly immunogenic when delivered by DNA. This approach helps to reduce the repeated boosters and enhance the immunity. Trails has been done with HIV env gene, which when given alone does not produce very good response but when boosted with recombinant env proteins, shows higher antibody titer.

\section{DNA vaccines currently in market}

Only 4 licensed DNA vaccines are available for animal use in the market.

1. Vaccine against West Nile virus for horse [33],

2. Against infectious haematopoietic necrosis virus

[34],

3. Against melanoma in dogs [35],

4. Growth hormone releasing hormone (GHRH) [36]. Marketed name, marketing company, year of license, properties of these approved vaccines are given in the Table- 4 .

\section{Conclusion}

DNA vaccines can be said as the treasure which the scientists are searching in order to combat incurable diseases like AIDS, TB. Since it uses only the plasmid DNA there is less chance of contamination and hence adverse effects are lesser. Once the cracks in case of stimulation of immunity are sealed then this new novel vaccine can be available in the market for all sorts of diseases. Thus it is for real that the DNA vaccine is getting ready for the 'Prime Time'.

\section{References}

1. Stewart, A.J. and Devlin, P.M. (2006). The history of the smallpox vaccine. J. Infect. 52(5):329-334.

2. Ada, G. (2005). Overview of vaccines and vaccination. Mol. Biotechnol.29(3):255-272.

3. Ingolotti, M., Kawalekar, O., Shedlock, D.J., Muthumani, K. and Weiner, D.B. (2010). DNA vaccines for targeting bacterial infections. Expert Rev Vaccines. 9(7): 747-763.

4. Sandoval, A.R and Ertl, H.C.J. (2001). DNA Vaccines. Current Molecular Medicine. 1(2):217-243.

5. Robinson, H. L. and Torres, C. A. (1997). Semin. Immunol. 9:271-283.

6. Tang, D.C., DeVit, M., Johnston, S.A. (1992). Genetic immunization is a simple method for eliciting an immune response. Nature, 356(6365):152-154.

7. Kowalczyk, D.W., Ertl, H.C. (1999). Immune responses to DNA vaccines. Cell. Mol. Life Sci. 55(5):751-770.

8. Ritter, T., Brandt, C., Prosch, S. et al., (2000). Stimulatory and inhibitory action of cytokines on the regulation of hCMV-IE promoter activity in human endothelial cells. Cytokine. 12(8):1163-1170.

9. Kutzler, M.A., Weiner, D.B. (2008). DNA vaccines: ready for prime time? Nature Reviews Genetics. 9:776-88.

10. Vanniasinkam, T., Reddy, S.T., Ertl, H.C. (2006). DNA immunization using a non-viral promoter. Virology. 344(2):412-420.

11. Lutz, C.S. (2008). Alternative polyadenylation: a twist on mRNA3'end formation. ACS Chem. Biol. 3 (10):609-617.

12. Broderick, K.E. et al., (2011). Optimization of Electroporation-Enhanced Intradermal Delivery of DNA Vaccine Using a Minimally Invasive Surface Device. Hum.Vaccines. 7:22-28.

13. Lui, M.A (2010). DNA vaccines: an historical perspective and view to the future. Immunol. Rev. 239: 62-84.

14. Verstrepen, B.E., Bins, A.D., Rollier C.S. et al., (2008). Improved HIV-1 specific T-cell responses by short-interval DNA tattooing as compared to intramuscular immunization 
in non-human primates. Vaccine. 26 (26):3346-3351.

15. Gopee, N.V., Cui, Y., Olson, G., Warbritton, A.R., Miller, B.J., Couch, L.H., Wamer, W.G., Howard, P.C. (2005). Response of mouse skin to tattooing: use of SKH-1 mice as a surrogate model for human tattooing. Toxicol Appl Pharmacol.209(2):145-158.

16. Lori, F., Calarota, S.A., Lisziewicz, J. (2007). Nanochemistry-based immunotherapy for HIV-1. Curr. Med. Chem. 14(18):1911-1919.

17. Watabe, S., Xin, K.Q., Ihata, A. et al., (2001). Protection against influenza virus challenge by topical application of influenza DNA vaccine. Vaccine. 19(31):4434-4444.

18. Fuller, D.H., Loudon, P., Schmaljohn, C. (2006). Preclinical and clinical progress of particle-mediated DNA vaccines for infectious diseases. Methods. 40(1):86-97.

19. Laddy, D.J. et al., (2009). Electroporation of Synthetic DNA Antigens Offers Protection in Nonhuman Primates Challenged with Highly Pathogenic Avian Influenza Virus. J. Virol. 83 (9): 4624-4630.

20. Xu, J., Ding, Y., Yang, Y. (2008). Enhancement of mucosal and cellular immune response in mice by vaccination with respiratory syncytial virus DNA encapsulated with transfersome. Viral Immunol. 21(4): 483-489.

21. Kanazawa, T., Takashima, Y., Hirayama, S., Okada, H. (2008). Effects of menstrual cycle on gene transfection through mouse vagina for DNA vaccine. Int. J. Pharm. 360(1-2):164-170.

22. Brave, A., Hallengard, D., Schroder, U., Blomberg, P., Wahren, B., Hinkula, J. (2008). Intranasal immunization of young mice with a multigene HIV-1 vaccine in combination with the $\mathrm{N} 3$ adjuvant induces mucosal and systemic immune responses. Vaccine. 26(40):5075-5078.

23. Guimaraes, V., Innocentin, S., Chatel, J.M., et al., (2009). A new plasmid vector for DNA delivery using lactococci. Genet. Vaccines Ther. 7(1):4.

24. Ulmer, J. B., Donnelly, J. J., Parker, S. E., Rhodes, G. H., Felgner, P. L., Dwarki, V. J., Gromkowski, S. H., Deck, R. R., DeWitt, C. M., Friedman, A. and et al .,(1993). Science, 259, 1745- 1749.

25. Fynan, E. F. et al., (1993). DNA vaccines: protective immunizations by parenteral, mucosal, and gene-gun inoculations. Proc. Natl Acad. Sci. USA. 90, 11478-11482.

26. Wang, B. et al., (1993). Gene inoculation generates immune responses against human immunodeficiency virus type 1 . Proc. NatlAcad. Sci. USA. 90, 4156-4160.

27. Ruprecht, R. M. (1999). Live attenuated AIDS viruses as vaccines: promise or peril? Immunol. Rev. 170, 135-149.

28. Kutzler, M.A. and Weiner, D.B. DNA vaccines: ready for prime time?.www.nature.com/reviews/genetics.retrieved on 29-05-2012.

29. Muthumani, K., Lankaraman, K.M., Laddy, D.J., et al., (2008). Immunogenicity of novel consensus-based DNA vaccines against Chikungunya virus. Vaccine. 26 (40): 5128 -5134 .

30. Olafsdottir, G., Svansson, V., Ingvarsson, S., Marti, E., Torsteinsdottir, S. (2008). In vitro analysis of expression vectors for DNA vaccination of horses: the effect of a Kozak sequence. Acta Vet. Scand, 50:44.

31. Kumagai, Y., Takeuchi, O., Akira, S. (2008). TLR9 as a key receptor for the recognition of DNA. Adv. Drug Deliv. Rev. 60(7):795-804.

32. Plotkin, S.A. (2003). Vaccines, vaccination, and vaccinology. J. Infect. Dis. 187(9):1349-1359.

33. Davidson, A. H. et al., (2005). Immunologic responses to West Nile virus in vaccinated and clinically affected horses. J.Am. Vet. Med. Assoc. 226, 240-245.

34. Garver, K. A., LaPatra, S. E. and Kurath, G. (2005). Efficacy of an infectious hematopoietic necrosis (IHN) virus DNA vaccine in Chinook Oncorhynchus tshawytscha and sockeye O. nerka salmon. Dis. Aquat. Organ. 64, 13-22.

35. Bergman, P. J. et al., (2006). Development of a xenogeneic DNA vaccine program for canine malignant melanoma at the Animal Medical Center. Vaccine, 24. 4582-4585.

36. Thacker, E. L. et al., (2006). Plasmid-mediated growth hormone-releasing hormone efficacy in reducing disease associated with Mycoplasma hyopneumoniae and porcine reproductive and respiratory syndrome virus infection. $J$. Anim. Sci. 84, 733-742. 